



\title{
Exploring the effects of a healthy school lunch on cognitive performance in Dutch primary school children within the Healthy School Lunch project
}

\author{
Authors: Coosje Dijkstra, Sandra van der Haar, Geertje van Bergen, Ellen van Kleef, \\ Monique Vingerhoeds \\ Institute: Vrije Universiteit Amsterdam, Wageningen Food \& Biobased Research, \\ Wageningen University \& Research
}

Date of publication: Mei 2020

This research project has been carried out by Wageningen Food \& Biobased Research, Wageningen University \& Research and Vrije Universiteit Amsterdam commissioned by the Dutch Ministry of Agriculture, Nature and Food Quality and funded by EZ and a consortium of partners, in the context of PPS Project de Gezonde Schoollunch (project number TKI-AF 16098; https://www.wur.nl/nl/show/Gezonde-schoollunch.htm). 
Version: final

Reviewer: Garmt Dijksterhuis

Approved by: Annelies Dijk

Client: the Dutch Ministry of Agriculture, Nature and Food Quality

Sponsor: EZ and a consortium of partners (https://www.wur.nl/nl/show/Gezonde-schoollunch.htm)

This report can be downloaded for free at https://doi.org/10.18174/519945 or at www.wur.eu/wfbr (under publications).

(C) 2020 Wageningen Food \& Biobased Research, institute within the legal entity Stichting Wageningen Research.

The client is entitled to disclose this report in full and make it available to third parties for review. Without prior written consent from Wageningen Food \& Biobased Research, it is not permitted to:

a. partially publish this report created by Wageningen Food \& Biobased Research or partially disclose it in any other way;

b. (let a third party) use this report created by Wageningen Food \& Biobased Research or the name of the report or Wageningen Food \& Biobased Research in whole or in part for the purposes of making claims, conducting legal procedures, for (negative) publicity, and for recruitment in a more general sense;

c. use the name of Wageningen Food \& Biobased Research in a different sense than as the author of this report.

PO box 17, 6700 AA Wageningen, The Netherlands, T + 31 (0)317 4800 84, E info.wfbr@wur.nl, www.wur.eu/wfbr. Wageningen Food \& Biobased Research is part of Wageningen University \& Research.

All rights reserved. No part of this publication may be reproduced, stored in a retrieval system of any nature, or transmitted, in any form or by any means, electronic, mechanical, photocopying, recording or otherwise, without the prior permission of the publisher. The publisher does not accept any liability for inaccuracies in this report. 


\section{Contents}

Summary 4

Samenvatting 5

$1 \quad$ Introduction $\quad 6$

2 State-of-the-art: lunch and cognition $\quad 7$

2.1 Introduction 7

$\begin{array}{lll}2.2 & \text { Long-term effects of lunch on cognition } & 7\end{array}$

2.3 Immediate effects of lunch on cognition 8

2.4 Effects of meal composition on cognition 9

3 Experimental design of a possible study towards the effects of a school lunch on cognition on primary school children

3.1 Introduction 11

3.2 Design and sample size calculation 11

3.3 Lunch composition and control condition 12

3.4 Eating conditions (fixed or ad libitum) 12

3.5 Cognitive measures 12

3.6 Setting of the study 13

4 Conclusions $\quad 14$

$\begin{array}{ll}\text { Literature } & 15\end{array}$

$\begin{array}{lll}\text { Annex } 1 & \text { Search strategy } & 17\end{array}$ 


\section{Summary}

The 'Healthy School Lunch' project (PPS Een gezonde schoollunch - TKI AF-16098) aimed to study the feasibility and impact of offering a healthy school lunch in Dutch primary schools. In the first phase of the project we studied the support for a healthy school lunch among a wide range of stakeholders and we explored what they thought a healthy school lunch should look like. The next phase aimed to study the effects of a healthy school lunch on dietary intake and cognitive performance. In order to investigate the effects of providing a healthy school lunch on the dietary intake of children during lunch, a longitudinal intervention study with three schools was designed, where a healthy school lunch was offered for six months. Due to various financial and methodological reasons that were not fully considered when starting this project, it was not possible to combine the dietary intake and cognition study in the school lunch intervention. Instead, we explored the possibilities and requirements to perform a solid experimental cross-over study on the effects of a healthy school lunch on cognitive performance within the Healthy School Lunch Project. This process is described in the current report. We started with a review of the literature on the effects of a healthy school lunch on cognitive performance of children. Studies on the immediate and transient effects of a healthy school lunch versus skipping lunch showed, on a variety of cognitive measures, small and inconsistent effects on alertness and working memory of children. Studies on the long-term effects of a healthy school lunch versus habitual lunch showed small improvements in concentration and language processing ability of children.

Given the restriction that long term effects of a school lunch on cognitive performance could not be examined within the scope of this project, the focus shifted to understanding immediate effects. A well-designed study to capture immediate effects of a healthy school lunch on cognitive performance of children within our project would require a strictly controlled cross-over design in a school setting. The intervention should consist of an ad libitum buffet-style healthy school lunch, compared with a control condition in which children eat ad libitum from a provided lunch comparable to the common relatively unhealthy packed school lunch of Dutch children. Finding an adequate measure for cognitive performance is hampered by the great variation of previously used measures across studies. These ranged from relatively indirect measures of concentration and disengagement to standardized computerized tests assessing specific cognitive domains such as alertness and higher-level executive functions. Hence, a comprehensive battery of tests would be advisable to explore various potential effects. Power calculations would be needed to determine the sample size of such a study, but it is clear that large numbers of children would be needed, given the small expected effects and methodological challenges. As more than one participating school would be needed, multilevel statistical models would be required to handle grouped and individual children's data. More research on the effects of a healthy school lunch on cognition in primary school children would be very useful. However, a well-designed study that would provide convincing evidence of the effects of a healthy school lunch on cognitive performance in primary school children, would require a high cost set-up that places a very high burden on both the children and the schools. Therefore, we decided that it is not realistic to perform this study within the Healthy School Lunch project. In this report we would like to share our findings, considerations and recommendations to researchers of future studies on the effect of healthy school lunches on cognitive performance in children. 


\section{Samenvatting}

Het project de 'Gezonde Schoollunch' (TKI AF-16098) onderzoekt de haalbaarheid en het effect van een verzorgde gezonde schoollunch op de basisschool in Nederland. In de eerste fase van het onderzoek hebben we onderzocht wat het draagvlak is van verschillende stakeholders voor een gezonde schoollunch en hoe een gezonde schoollunch er volgens hen uit moet zien. De tweede fase van het onderzoek had als doel om het effect van een gezonde schoollunch op de voedingsinname en cognitieve prestaties bij kinderen te onderzoeken. Om het effect van de gezonde schoollunch op de voedingsinname te onderzoeken hebben we een interventiestudie van een half jaar uitgevoerd op drie Nederlandse basisscholen. Door verscheidene financiële en methodologische uitdagingen die we bij de start van dit project niet voorzien hadden, bleek het niet mogelijk om de voedingsinnamestudie en de cognitieve studie te combineren. In plaats daarvan hebben we onderzocht wat de mogelijkheden en voorwaarden zijn voor het uitvoeren van een cross-sectioneel onderzoek naar de effecten van een gezonde schoollunch op cognitieve prestaties van basisschoolleerlingen binnen het project de Gezonde Schoollunch. Dit proces wordt beschreven in dit rapport.

Als eerste is een literatuurstudie uitgevoerd naar het effect van een gezonde schoollunch op een verscheidenheid aan cognitieve uitkomstmaten. Deze literatuurstudie liet zien dat een gezonde schoollunch (in vergelijking met geen lunch) op de korte termijn (i.e. kort na inname van de schoollunch), kleine maar inconsistente effecten kan hebben op de alertheid en het werkgeheugen van kinderen. Langetermijneffecten van een gezonde schoollunch (in vergelijking met een gewone lunch) lieten kleine verbeteringen zien in concentratie en taalverwerking van kinderen.

Aangezien het bestuderen van de lange termijn effecten van een gezonde schoollunch op cognitieve vaardigheden van kinderen niet kon worden onderzocht binnen de scope van dit project, is de focus verlegd naar effecten die kort na de lunch optreden (immediate effects). Een optimaal ontworpen studie naar de korte termijneffecten van een gezonde schoollunch op de cognitieve prestaties van de kinderen zou een strikt gecontroleerde cross-over studie inhouden met drie meetmomenten, die uitgevoerd wordt in de schoolomgeving. De interventie zou kunnen bestaan uit een gezond ad libitum lunchbuffet dat wordt vergeleken met een controleconditie waarin kinderen een lunch krijgen die lijkt op de standaardlunch van Nederlandse kinderen. Aangeraden wordt om een batterij aan cognitieve tests te gebruiken om zo verschillende effecten op cognitie te kunnen verkennen. Een powerberekening is nodig, maar het is duidelijk dat een groot aantal kinderen nodig zal zijn vanwege de eerder gevonden kleine effecten zijn en de vele methodologische uitdagingen. Hierbij moet methodologisch rekening gehouden worden met de geclusterde resultaten per school en klas en daarom zal een multi-level design en analyses nodig zijn.

Hoewel meer onderzoek naar de effecten van een gezonde schoollunch op de cognitie bij kinderen op de basisschool is gerechtvaardigd, vraagt een goed ontworpen studie die overtuigend bewijs zou kunnen leveren om een aanpak, inzet en financiële belasting die aanzienlijk is. De belasting van scholen en kinderen bij een dergelijke studie is enorm hoog. Daarom hebben we besloten dat het niet realistisch is om dit onderzoek binnen het lopende project uit te voeren. We raden onderzoekers die dit willen gaan onderzoeken aan om de uitdagingen en aanbevelingen beschreven in dit rapport zorgvuldig te lezen en te overwegen. 


\section{Introduction}

As in many Western countries, Dutch children do not eat healthily enough. Studies showed that they eat too few healthy products like fruit and vegetables and consume too many unhealthy products like sugary drinks, and sweet and salty snacks. An adequate nutrition in the early life stages of children is important, not only for preventing serious health implications throughout life, but also for optimizing development and quality of life in adulthood.

Children spent a large proportion of their time in school. Therefore, public health interventions like a healthy lunch organized in the school setting represent an ideal setting to promote healthy dietary habits. In the Netherlands there is a trend towards more primary schools having a continuous timetable instead of a morning and afternoon programme with a long break in between. This results in a growing number of Dutch children who are eating their lunch at school, instead of at home. This opens up possibilities to provide a healthy school lunch at primary schools, which has been shown to contribute to a healthy diet in other countries (e.g. Miyawaki, Lee, \& Kobayashi, 2018).

The project a Healthy School Lunch (Een gezonde schoollunch - TKI AF-16098) aims to study the feasibility and impact of a healthy school lunch in Dutch primary schools. In the first phase of the project the support for a healthy school lunch in the Netherlands was studied and we explored what a healthy school lunch should look like according to a wide range of stakeholders. The next phase aimed to study the effects of a healthy school lunch on dietary intake and cognitive performance in Dutch primary schoolchildren, by a 6-month intervention at three primary schools.

In order to investigate the effects of providing a healthy school lunch on the dietary intake of children during lunch we designed a longitudinal intervention study with three schools where a healthy school lunch was offered for six months. In this intervention setting, children have only access to healthy food products. The decision to choose only three intervention schools was mainly a practical and financial one since it was difficult to find schools willing to participate in a study with a fairly radical intervention and because the provision of a free school lunch for six months is expensive. We were planning to combine this longitudinal study with a study investigating the effect of the healthy school lunch on cognition. However, in order to properly investigate this question it would have been necessary to include much more schools because schools have a hierarchical or clustered structure (one individual child is in a class, which is in a school, each with its own statistical variation) which requires a multilevel approach. Due to limited financial resources and the difficulty in finding schools to participate, it was not possible to include more intervention schools. Therefore, already at an early stage in the project, it was decided not to combine the two studies, one on the effects of providing a healthy school lunch on dietary intake and the other one on the effects on cognition.

Instead, we explored the possibilities and requirements to perform an solid experimental cross-over study on the short-term effects of a healthy school lunch on cognition. This report presents a brief overview of the state of the art of the effects of lunch on cognition in children (Chapter 2). Chapter 3 presents the possible experimental set-up and requirements for studying the effects of a school lunch on cognition. Chapter 4 discusses the implications of previous research (chapter 2 ) and the experimental study design requirements of an optimally designed study to understand effects of a healthy school lunch on cognitive performance of children in the school setting (chapter 3 ). This chapter 4 additionally explains why it was decided to not pursue such a study within the current project.

This report is intended for the consortium partners, steering committee, TKI agency and other interested people. 


\section{State-of-the-art: lunch and cognition}

\subsection{Introduction}

A literature search was performed to capture key studies on the effect of lunch at primary schools on various cognitive outcomes. This search was performed by an information specialist from the Wageningen University library (see Annex 1). Additional articles were added to this collection via reference lists in these articles.

Seven articles focused directly on the effects of lunch on cognition in children in a school setting. These articles can be subdivided into studies examining long-term effects (four articles), i.e. effects that become clear after repeatedly providing a healthy lunch for a longer period of time, and studies focusing on immediate effects (three articles), which are transient effects that occur shortly after lunch intake. These articles will be discussed in Sections 2.2 and 2.3, respectively. In addition, some literature is added about the effects of meal composition and cognition in children (section 2.4). When reading this chapter, it is important to realize that cognition is not a uniform concept. It is used as an umbrella term to cover a wide range of cognitive functions and processes, which include attention, (working) memory, inhibitory control, language, problem solving, planning and reasoning ability, and information processing speed. The current chapter does not aim to give an exhaustive overview of the literature on all these cognitive domains and how these can be assessed (for reviews, see e.g. Adolphus et al., 2017; Isaacs \& Oates, 2008).

\subsection{Long-term effects of lunch on cognition}

First we will discuss a project most relevant to our study, i.e., the OPUS School Meal project (Sørensen et al., 2016; Sørensen et al., 2015). The OPUS School Meal project is an intervention study executed in primary schools in Denmark, investigating whether serving healthy school meals influences concentration and school performance in 739 school children aged 8-11 years. In a clusterrandomized controlled cross-over trial, a three-month healthy school meal program (the New Nordic Diet; NND) was compared with a three-month period of having a habitual packed lunch from home. At baseline and at the end of each three-month period, various aspects of cognition were measured, whereby concentration performance was chosen as the primary outcome measure. Concentration performance was defined as the number of correctly marked targets minus the number of omission errors in the $\mathrm{d} 2$ test of attention. The $\mathrm{d} 2$ test of attention is a neuropsychological measure of selective and sustained attention and visual scanning speed. It is a paper and pencil test that asks participants to cross out any letter "d" with two marks around above it or below it in any order (for details, see Sørensen et al., 2015). Additional cognitive measures included reading performance and mathematics skills. Results from the primary outcome measure showed no evidence that the school meal intervention influenced concentration performance as defined above, although an effect was found on a secondary measure. The percentage of omission errors in the $d 2$ test of attention was slightly (but statistically significantly) higher after the intervention period (median $1.46 \%$ ) than after the control period (median $1.37 \%$ ), raising the possibility that the healthy school lunch intervention negatively impacted cognition, i.e. increased inattentiveness and/or impulsivity (Sørensen et al., 2015). In addition, the school meal intervention statistically significantly improved children's reading performance (in terms of both processing speed and comprehension accuracy) relative to the control condition. No evidence was found for intervention effects on children's mathematical skills. Additional analyses of the same data set (Sørensen et al., 2016) revealed that the previously attested negative intervention effects on concentration (inattentiveness) and positive effects on reading performance were statistically significantly moderated by individual differences. Positive intervention effects on reading performance and negative intervention effects on $\mathrm{d} 2$ omission errors were stronger in boys, in children from families with a higher education level and in children with normal to good baseline reading proficiency. The authors concluded that the lunch intervention had differential effects on different subgroups, and may hence decrease socioeconomic inequality in some respects while increasing it in others. 
Two other publications report the effects of a healthy school lunch intervention on learning-related classroom behaviour in primary (school years 3-5; age range about 7-10; (Golley et al., 2010)) and secondary (school years 7 and 9; age range about 11-12 and 13-14;(Storey et al., 2011)) school children in England. The aim was to investigate whether a 12-week healthy school food intervention would improve children's learning-related classroom behaviour after lunch. A two-phase intervention program was implemented at eight schools, consisting of (1) providing and promoting healthier school food at lunchtime ( 6 weeks) and (2) improving the school dining room environment (e.g., physical setting, lunch time routine, lunch time behaviour management; 6 weeks); the order of the two phases was counterbalanced between schools. The eight intervention schools were compared with four control schools in which no intervention took place. Systematic observations of on-task and off-task behaviours in the classroom were used as proxies for concentration/alertness and disengagement, respectively. Observations were performed in 146 primary and 156 secondary school children, randomly sampled from intervention and control schools, at baseline and after three months. Findings showed a statistically significant intervention effect, such that secondary school children in the intervention group were $18 \%$ more likely to be on-task, and $14 \%$ less likely to be off-task than children in the control group (Storey et al., 2011). In primary school children, on-task behaviour in teacher-pupil interactions was 3.4 times more likely in children from intervention schools when compared with children from control schools. As for pupil-pupil interactions, however, on-task behaviour was statistically significantly less likely, and off-task behaviour statistically significantly more likely in children from the intervention schools relative to children form the control schools, suggesting that if increased alertness is not channelled and supervised, it may yield increased off-task behaviour when children are working together (Golley et al., 2010). Concluding, these findings offer some support for the hypothesis that healthy school food in combination with improvements in the dining room can positively influence concentration in primary and secondary school children. However, findings remain inconclusive as to whether the reported increases in concentration and decreases in disengagement can be directly linked to a healthier school lunch, or whether the effects were due to changes in the dining environment.

\subsection{Immediate effects of lunch on cognition}

Three articles investigating the immediate effects of lunch on cognition in school children all stem from the same research group in Germany (the Research Institute of Child Nutrition in Dortmund). This research group performed three intervention studies: the Cognition Intervention Study Dortmund (CogniDo; Müller et al., 2013), the Cognition Intervention Study Dortmund PLUS (CogniDo PLUS; Schröder et al., 2015) and the Cognition Intervention Study Dortmund Continued (CoCo; Schröder et al., 2016). All three studies compared the effects of having lunch with skipping lunch, on cognition in German primary school children.

In the first study (Müller et al., 2013), a randomized cross-over study was performed in 105 children (12-13 years old) on two test days (skipping lunch on one day vs. having lunch on the other) which were embedded in everyday school life. On the lunch day, lunch was served by the school kitchen staff at the school's usual lunch time; on the skipping lunch day, water was offered at usual lunch time and lunch was eaten directly after cognitive testing. On both days, the children consumed a standardized morning snack (ad libitum) during the morning break. Children performed three computerized tests to assess (1) alertness, (2) visuospatial working memory and (3) selective attention, 45 minutes after the usual lunch. Findings provided no evidence for a difference between having and skipping lunch on children's visuospatial working memory or selective attention. Only a trend for an effect was reported on alertness: the authors found no differences between conditions in mean reaction times, but a trend toward greater deviations of mean reaction times (interpreted as larger variability in attention) after skipping lunch ( $84 \mathrm{~ms}$ ) than after having lunch ( $77 \mathrm{~ms}$ ), giving rise to the possibility of a positive effect of having lunch on alertness. Note that these effects were only trends, so not statistically significant.

The second study (Schröder et al., 2015) was similar to the first (Müller et al., 2013), but the objective was extended by investigating to what extent potential lunch-related changes in cognition were moderated by an increase in postprandial cortisol. Cortisol is a hormone that increases appetite. It was hypothesized that (not yet fully developed) cognitive functions in children may be more sensitive to environmental influences (including meal-induced changes in cortisol levels) than those in 
adults, which could potentially give rise to enhanced impairments in cognitive performance after lunch intake (also known as the 'post-lunch dip'). To this end, effects of having vs. skipping lunch on cognition were investigated in 194 German primary school children (11-12 years old). The design was the same as the design of the first study, but cognition assessment focused on three higher-level cognitive domains (i.e. executive functions): (1) cognitive flexibility (or task-switching); (2) working memory updating, and (3) interference control (the ability to selectively attend to task-relevant input while ignoring conflicting task-irrelevant cues). In addition, saliva samples were collected twice on each test day (before lunch and before the cognitive assessment) to examine the saliva-cortisol status. Results from this second study provided no evidence for a 'post-lunch dip' in children. No differences were found between having lunch and skipping lunch in task switching or interference control, but a positive effect of having lunch was found on working memory updating: while performing a two-back test, children exhibited fewer false alarms (i.e., fewer responses where no response was required) in the having-lunch condition relative to the skipping-lunch condition. Additional analyses revealed that this effect was restricted to children who showed a large increase in cortisol levels after lunch, suggesting that the mechanism underlying the positive effect of having lunch on working memory updating may relate to meal-induced postprandial increases of plasma cortisol.

A third study (Schröder et al., 2016) investigated effects of having lunch on cognition in 154 German primary school children (aged 10-12 years) 90 minutes after finishing lunch. The time after food intake in this study was thus twice as long as in the two previously conducted studies. It was hypothesized that a potential post-lunch dip in children may appear later in the afternoon, given that the post-lunch dip in adults is typically observed 60-120 minutes after lunch. This third study focused on the cognitive domains that are expected to be most likely affected by the lunch manipulation based on the above-mentioned findings (Müller et al., 2013; Schröder et al., 2016), i.e. alertness, working memory updating and task switching. Results from this last study (Schröder et al., 2016) did not replicate the findings from the first two studies (Müller et al., 2013; Schröder et al., 2015): no evidence was found for a lunch-related improvement, nor for a lunch-related decline in performance on any of the cognitive tasks. The researchers speculatively relate their findings to the course of blood glucose levels: lunch-induced increased blood glucose levels may have been decreasing again at the time of testing in the third study, which may have attenuated the positive effects on cognitive performance attested in the first two studies.

\subsection{Effects of meal composition on cognition}

Performance decline and sleepiness in the early afternoon are also known as the 'post-lunch dip'. No research was found on the relationship between lunch meal composition and this post lunch dip, but research on the composition of breakfast has shed some light on this issue. These studies have explored meal-induced changes in how reductions in Glycaemic Index (GI) or Glycaemic Load (GL) of breakfast may enhance cognitive performance in children shortly after eating (Benton, Maconie, \& Williams, 2007; Ingwersen, Defeyter, Kennedy, Wesnes, \& Scholey, 2007; Mahoney, Taylor, Kanarek, \& Samuel, 2005; Wesnes, Pincock, Richardson, Helm, \& Hails, 2003). The GI refers to a measure that indicates how rapidly carbohydrates are broken down into glucose and released in the bloodstream compared to a reference product. Since the portion size of the food that is consumed is a major determinant of the GI, the GL is a related measure that takes into account the amount of carbohydrates in the food, prior to digestion. Several studies showed that a more prolonged glucose response of breakfast may have positive effects on sustained cognitive performance. Prior research comparing effects of different breakfast types on cognition suggests that lower-GI breakfasts may facilitate cognition relative to higher-GI breakfasts (Adolphus et al., 2017).

In a systematic review of Edefonti and colleagues (Edefonti et al., 2014), the existing evidence on the role of specific characteristics of an adequate breakfast, whereby the role of GI and GL on cognitive and academic performance on children, adolescents and adults was reviewed. Cognitive and academic performance were investigated by looking at multiple domains, including memory, attention, reasoning, learning and verbal and math abilities, with a variety of test batteries scheduled at different time points in the morning. The authors concluded that there is emerging, but still equivocal evidence that a lower after-meal glycaemic response is beneficial to cognitive performance. A recent systematic review and meta-analysis (Álvarez-Bueno et al., 2019) discusses the existing evidence on the effects 
of a high GI versus a low GI breakfast on cognitive functions, including memory and attention, of children and adolescents. The authors conclude that different GI breakfasts do not affect cognitive domains in children and adolescents except for an effect on delayed memory in children. 


\section{Experimental design of a possible study towards the effects of a school lunch on cognition on primary school children}

\subsection{Introduction}

This chapter discusses the implications of previous research on the set-up of the study on the effects of a school lunch on cognitive outcomes within the Healthy School Lunch Project, as well as the major challenges associated with this study in light of the time and budgetary limitations of the current project.

\subsection{Design and sample size calculation}

To control for inter-individual variability in a large number of factors known to affect cognition (such as age, gender and socio-economic status) it is recommended that the study follows a cross-over design. In such a design, each participant is exposed to all experimental conditions: each child gets a healthy lunch on one day and an unhealthy lunch on another day (order randomized across participants). In both lunch conditions, cognitive performance should be assessed after lunch intake, and compared to the baseline measurement. The effects of lunch type should be assessed by comparing difference scores, that is, comparing [healthy lunch - baseline] scores vs. [unhealthy lunch - baseline] scores. This means that each child should perform the test battery three times. Alternatively, an additional training session could be included in which children practice the cognitive tests before the actual start of the study (Brindal et al., 2013; Muthayya et al., 2007; Schröder et al., 2016), but this would significantly increase the duration (and costs) of the total experiment. A consequence of the proposed cross-over design is an increased number of testing sessions per child, which leads to a greater burden for children involved in the experiment. At the same time, performing the same tests multiple times may yield learning effects (i.e., the same task becoming easier with increased experience), which have to be taken into account when analyzing the results.

In a review of the literature on effects of breakfast and breakfast composition on cognition in children and adults (Adolphus et al., 2017), it is concluded that the majority of studies in the field is statistically underpowered. Underpowered studies may lead to missing potentially effects, and prevent researchers from drawing conclusions in the case of null findings. We point out that small effect sizes and large individual differences may also contribute to the inconsistent findings of different authors. A proper a priori power calculation is ideally based on effect sizes reported in previous research.

However, given the scarcity of research in this domain, reported effects are inconclusive, and obtained from different tasks. Moreover, previously reported effects are all based on a having lunch versus fasting contrast, whereas we are interested in the benefits of a healthy over a less healthy lunch. This less extreme contrast is expected to yield modulations of previously reported effects (i.e., smaller effect sizes). In order to detect such small effects, a substantially larger sample size would be needed than those used in the studies discussed above (where samples ranged from 105 to 194 children). 


\subsection{Lunch composition and control condition}

In the Healthy School Lunch project the main interest is investigating the effects of a healthy school lunch in comparison with a usual packed lunch from home. As discussed in Chapter 2, studies on immediate and transient effects of lunch on cognition so far have investigated differences in cognitive performance between having lunch and skipping lunch. In the Dutch primary school context the vast majority of children have lunch every day by which the ecological validity of comparing a having-lunch with a no-lunch condition would be very low and thereby not relevant.

Based on the experience gained in the current project (Rongen et al., in preparation) two lunch conditions are proposed:

- A healthy school lunch based on the Guidelines of the Dutch Nutrition Center, where at least $80 \%$ of the offered lunch is within the "Wheel of Five", and maximally $20 \%$ of the offered lunch are products that are recommended to have maximally 3-5 times per day.

- A school lunch based on the usual lunch, where the content is the same as the packed lunches from home which are investigated at baseline.

\subsection{Eating conditions (fixed or ad libitum)}

An important aim of the Healthy School Lunch Project is to offer a lunch that matches what children are used to eat. In the set-up of the study, there are basically two options in offering a school lunch: an ad libitum lunch, where children can eat what and how much they like, or a fixed school lunch (each child is offered the same lunch and instructed to finish it). Providing children with a fixed lunch compared to an ad libitum lunch would allow for better control over children's food intake, but the underlying "one-size-fits-all" assumption is problematic, as deviation from habitual intake can adversely affect cognitive performance (Lloyd et al., 1994, cited in (Adolphus et al., 2017)). It is pointed out that serving lunch ad libitum induces inter-individual variation. When served in buffet style, the same lunch condition may greatly differ from child to child in terms of meal composition (for example GI / GL). When choosing for an ad libitum lunch, it is hence crucial to carefully monitor food intake in children, not only during, but also before and after lunch.

Taking into consideration all above mentioned aspects, we suggest to provide an ad libitum lunch buffet, where the actual intake is monitored to calculate the nutritional values of the lunch, as well as the GI and GL. In addition, cortisol levels can be measured in saliva before and after the lunch to relate the results to a possible post-lunch dip (Schröder et al., 2015).

\subsection{Cognitive measures}

The aim of the Healthy School Lunch Project is to measure cognitive performances as precise and sound as possible. Previous research provides too little evidence to a priori predict which aspect(s) of cognition are most likely affected by a healthy lunch in primary school children. Studies used a variety of tasks, and report both positive and negative effects, as well as null findings in various cognitive domains. Given the scarcity of prior research, and the variation in tasks and findings, we have asked advice from experts from the Amsterdam UMC location AMC. They suggested us to use a combination of cognitive measures to assess effects on multiple cognitive domains. Using multiple tests allows for a replication of previous studies reporting immediate effects of lunch on specific cognitive functions (such as attention and working memory updating) (Schröder et al., 2015, 2016), as well as for an exploration of potential effects in other cognitive domains. The experts advised us to use the Emma Toolbox (Konigs, in preparation). This toolbox is an in-house designed battery of computerized tests that assesses the following neurocognitive domains: information processing, attention, learning \& memory, executive functioning and sensory \& motor functioning. The toolbox combines validated and experimental tests, allowing outcome measurement as well as exploration of the etiology of neurocognitive impairment. To these ends, the toolbox uses built-in control conditions and parametric difficulty manipulation to isolate the effects of neuropathology on specific neurocognitive processes. 
The broad range of neurocognitive domains covered by the toolbox also allows neurocognitive profiling of patient groups. Lastly, the toolbox is designed to facilitate advanced analysis of task performance based on intra-individual data distributions (e.g. Ex-Gaussian analysis, Diffusion Model analysis), allowing the assessment of aspects of information processing (e.g. strategy, efficiency of the neurocognitive process and response execution) or intra-individual variability (i.e. lapses of attention, a hallmark feature of inattentive and impulsive behavior). The toolbox is administered on a 15-inch laptop and has a duration of $75 \mathrm{~min}$. Tests are assessed one by one. All tests are presented as games, therefore children are typically enthusiastic to complete the measurements.

However, an important consequence of including multiple cognitive measures rather than a single test is the increased length of the test sessions. From a methodological perspective, longer test sessions increase the cognitive load on the children, which may affect their cognitive performance (e.g., fatigue effects). One way of evening out potential fatigue effects would be to systematically vary the order of tests across children. From a practical point of view, longer testing sessions cause larger disruptions of the regular school program, which puts a larger burden on children and teachers alike. This will make it more challenging to convince schools to participate in the study and reach the required sample size. Another point of discussion in the design of the study is the time children have to consume their lunch and the timing of the cognitive assessment. In the Netherlands, the average lunch time at school for children is 15 minutes, followed by about 30 minutes playing outside. Within the current project it became clear that 15 minutes is insufficient to have a healthy school lunch from a lunch buffet. Therefore, it is needed to give children 20 minutes to consume their lunch, followed by a 30-minutes break during which they can play outside, after which the cognitive assessment takes place.

\subsection{Setting of the study}

There are different possible settings for performing a study on the lunch and cognition with children, for example at school or in a laboratory setting, whereby each setting has its own drawbacks and advantages. Performing the proposed study in a lab setting vs. a real life setting (school) has the advantage of increased experimental control (e.g., control over food intake before, during and after lunch, control over the testing environment). However, a lab setting does not only place a high burden on the children and their caretakers (who will have to come to the lab multiple times outside regular school hours), it also drastically lowers the ecological validity of the study. A methodological downside of testing children in real-life contexts is a substantial loss of experimental control, which decreases the likelihood of detecting true effects. Counteracting this introduces a need for a much larger sample size. For instance, the hypothesized relation between blood glucose levels and cognitive performance limits the post-lunch time frame to perform the tests with all children. At the same time, the computerized nature of the proposed test battery requires that children be tested individually. As a consequence, it will not be possible to test all participating children on the same day. A weekly school program will differ in the cognitive load of the lessons taught each day, which in turn may affect children's performance on the cognitive tests. Such inherent variability that comes with an everyday school setting asks for a substantial increase in the sample size to be able to detect a true effect of lunch on cognition. Given the project's overall goal to increase support for implementation of a healthy school lunch, the effects obtained from the proposed study should be generalizable to the children's daily life and environment and therefore, it is recommended to test children in a school setting. 


\section{Conclusions}

From the overview of the state-of-the-art in the field, it can be concluded that well-designed research investigating the effects of having a healthy lunch on cognition in school children is scarce. Previously reported effects are small and in need of further validation, but findings give rise to the possibility that having a healthy school lunch has an immediate positive effect on alertness and working memory, whereas concentration and language processing may benefit from longer-term lunch interventions. Note, however, that findings from studies investigating immediate effects are based on a comparison of having versus skipping lunch, whereas studies investigating long-term effects on cognition compared a healthy school lunch with habitual lunch intake. Moreover, assessments of cognition varied greatly across studies (from relatively indirect measures of concentration and disengagement to standardized computerized tests assessing specific cognitive domains such as alertness and higherlevel executive functions). Based on the literature review we conclude that as for the Healthy School lunch project, a well-designed study investigating the role of a healthy school lunch on cognition in children would add valuable insights to the scientific literature in this domain.

However, performing a decent study on the effects of lunch on cognitive performance of primary school children is challenging. Initially, the aim was to measure cognition in our longitudinal study on the effects of a healthy school lunch on dietary intake. However, in order to properly investigate this topic it would have been necessary to include much more schools and we had to finance much more lunches, which was not possible due to limited financial resources. Therefore it was already decided at an early stage not to combine the studies on the effect of providing a healthy school lunch on dietary intake and cognition. Instead, the possibilities were explored to perform an experimental cross-over study on the short term effects of a healthy school lunch on cognition that in theory sounds promising, but also raised some challenges when viewed in the light of the Healthy School Lunch project. First of all, due to the cross-over design of the study each child has to perform the test battery to measure cognition 3 times, which leads to a great burden for children involved in the study. This has also consequences for the recruitment of study participants, which is already difficult in studies in primary schools. It also raises the question if such a design (with a less healthier control condition) will be approved by the medial ethical committee. Although the use of the Emma Toolbox for the measurement of cognition sounds promising and provides us with the possibility to measure a wide range of cognitive domains, the collection time per test per child is long and the assessment of the test is individual. This places a high burden on the effort of the researcher and child and is thus expensive. Second, it is suggested that the vast majority of the studies performed in the field is underpowered. The presented effect sizes on short term effects of lunches on cognition are small and the individual differences in the measurement of cognition large which means that we need a substantially larger sample size than the studies performed so far. This is again a challenge in the recruitment, and it is also expensive.

In conclusion, although more research on the effects of a healthy lunch on cognition in school children is warranted, a well-designed study that would provide convincing evidence of the effects of a healthy school lunch on cognition in school children requires a set-up that places a high burden on children and schools because of the cross-over design and the comprehensive measurement of cognition. Moreover, many participants are needed and long-term effects of the lunch on cognition remain underexposed. Therefore, we decided that it was not realistic to perform the study within the Healthy School Lunch project and we recommend future studies to carefully consider the challenges raised in this report. 


\section{Literature}

Adolphus, K., Bellissimo, N., Lawton, C. L., Ford, N. A., Rains, T. M., de Zepetnek, J. T., \& Dye, L. (2017). Methodological challenges in studies examining the effects of breakfast on cognitive performance and appetite in children and adolescents. Advances in Nutrition, 8(1), 184S-196S.

doi:10.3945/an.116.012831

Álvarez-Bueno, C., Martínez-Vizcaíno, V., Jiménez López, E., Visier-Alfonso, M. E., Redondo-Tébar, A., \& Cavero-Redondo, I. (2019). Comparative Effect of Low-Glycemic Index versus High-Glycemic Index Breakfasts on Cognitive Function: A Systematic Review and Meta-Analysis. Nutrients, 11(8), 13. doi:10.3390/nu11081706

Benton, D., Maconie, A., \& Williams, C. (2007). The influence of the glycaemic load of breakfast on the behaviour of children in school. Physiology \& Behavior, 92(4), 717-724.

Brindal, E., Baird, D., Slater, A., Danthiir, V., Wilson, C., Bowen, J., \& Noakes, M. (2013). The effect of beverages varying in glycaemic load on postprandial glucose responses, appetite and cognition in 10-12-year-old school children. British Journal of Nutrition, 110(3), 529-537. doi: $10.1017 /$ S0007114512005296

Edefonti, V., Rosato, V., Parpinel, M., Nebbia, G., Fiorica, L., Fossali, E., . . Agostoni, C. (2014). The effect of breakfast composition and energy contribution on cognitive and academic performance: a systematic review. American Journal of Clinical Nutrition, 100(2), 626-656. doi:dx.doi.org/10.3945/ajcn.114.083683

Golley, R., Baines, E., Bassett, P., Wood, L., Pearce, J., \& Nelson, M. (2010). School lunch and learning behaviour in primary schools: An intervention study. European Journal of Clinical Nutrition, 64(11), 1280-1288. doi:10.1038/ejcn.2010.150

Ingwersen, J., Defeyter, M. A., Kennedy, D. O., Wesnes, K. A., \& Scholey, A. B. (2007). A low glycaemic index breakfast cereal preferentially prevents children's cognitive performance from declining throughout the morning. Appetite, 49(1), 240-244.

Isaacs, E., \& Oates, J. (2008). Nutrition and cognition: Assessing cognitive abilities in children and young people. European Journal of Nutrition, 47(SUPPL.3), 4-24. doi:10.1007/s00394-008-3002-y

Mahoney, C. R., Taylor, H. A., Kanarek, R. B., \& Samuel, P. (2005). Effect of breakfast composition on cognitive processes in elementary school children. Physiology and Behavior, 85(5), 635-645. doi: $10.1016 /$ j.physbeh.2005.06.023

Miyawaki, A., Lee, J. S., \& Kobayashi, Y. (2018). Impact of the school lunch program on overweight and obesity among junior high school students: a nationwide study in Japan. Journal of Public Health, 41(2), 362-370. doi:10.1093/pubmed/fdy095

Müller, K., Libuda, L., Gawehn, N., Drossard, C., Bolzenius, K., Kunz, C., \& Kersting, M. (2013). Effects of lunch on children's short-term cognitive functioning: A randomized crossover study. European Journal of Clinical Nutrition, 67(2), 185-189. doi:10.1038/ejcn.2012.209

Muthayya, S., Thomas, T., Srinivasan, K., Rao, K., Kurpad, A. V., van Klinken, J. W., ... de Bruin, E. A. (2007). Consumption of a mid-morning snack improves memory but not attention in school children. Physiology and Behavior, 90(1), 142-150. doi:10.1016/j.physbeh.2006.09.025

Schröder, M., Müller, K., Falkenstein, M., Stehle, P., Kersting, M., \& Libuda, L. (2015). Short-term effects of lunch on children's executive cognitive functioning: The randomized crossover Cognition Intervention Study Dortmund PLUS (CogniDo PLUS). Physiology and Behavior, 152, 307-314. doi: $10.1016 /$ j.physbeh.2015.09.025

Schröder, M., Müller, K., Falkenstein, M., Stehle, P., Kersting, M., \& Libuda, L. (2016). Lunch at school and children's cognitive functioning in the early afternoon: Results from the Cognition Intervention Study Dortmund Continued (CoCo). British Journal of Nutrition, 116(7), 1298-1305. doi: $10.1017 /$ S0007114516002932

Sørensen, L. B., Damsgaard, C. T., Petersen, R. A., Dalskov, S. M., Hjorth, M. F., Dyssegaard, C. B., ... et al. (2016). Differences in the effects of school meals on children's cognitive performance according to gender, household education and baseline reading skills. European Journal of Clinical Nutrition, 70(10), 1155-1161. doi:10.1038/ejcn.2016.99 
Sørensen, L. B., Dyssegaard, C. B., Damsgaard, C. T., Petersen, R. A., Dalskov, S. M., Hjorth, M. F., . . . Egelund, N. (2015). The effects of Nordic school meals on concentration and school performance in 8- to 11-year-old children in the OPUS School Meal Study: a cluster-randomised, controlled, crossover trial. British Journal of Nutrition, 113(8), 1280-1291.

doi:https://dx.doi.org/10.1017/S0007114515000033

Storey, H., Pearce, J., Ashfield-Watt, P., Wood, L., Baines, E., \& Nelson, M. (2011). A randomized controlled trial of the effect of school food and dining room modifications on classroom behaviour in secondary school children. European Journal of Clinical Nutrition, 65(1), 32.

Wesnes, K. A., Pincock, C., Richardson, D., Helm, G., \& Hails, S. (2003). Breakfast reduces declines in attention and memory over the morning in schoolchildren. Appetite, 41(3), 329-331. 


\section{Annex 1 Search strategy}

Search performed by an information specialist of the WUR library on 11 of January 2019

\section{$1.1 \quad$ Initial Search}

\section{S1 Population}

TITLE-ABS-KEY(child* OR school-aged OR school OR "primary school" OR "school child*" OR childhood OR "school age" OR "elementary school")

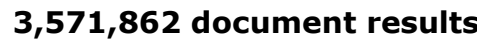

\section{S2 Intervention}

TITLE-ABS-KEY ( lunch OR "school meal" OR "school intervention" OR "healthy meal" OR "food services" OR diet OR "school health services" OR "dietary intake" OR "school lunch" OR classroom OR "lunch size" OR "lunch composition" )

969,651 document results

\section{S3 Outcome(1)}

( TITLE-ABS-KEY ( cogniti* OR neurocogniti* OR learning OR "academic performance" OR "school performance" OR "academic

skills" OR memory $O R$ attention $O R$ inattention $O R$ impuls* $O R$ concentration $O R$ "reaction time" OR "executive function" ) OR TITLE-ABS-KEY ( "lunch-dip" OR "lunch dip" OR "postpriandal period" )

\section{$7,902,924$ document results}

\section{S4 Outcome (2)}

( TITLE-ABS-KEY (

memory $O R$ attention $O R$ inattention $O R$ impuls* $O R$ concentration $O R$ "reaction time" ))

\section{$6,291,874$ document results}

\subsection{Final query}

Based on above results, the queries were simplified to focus on the relevant literature:

( TITLE-ABS-KEY ( child* AND lunch* AND ( cognition OR "cognitive function" OR "executive function" )) )

\section{5 document results}

Terms physical (activity), Breakfast, adolescent* removed, 30 remaining documents.

Transferred to EndNote, deleted a few titles manually (papers on autism, hearing impaired children, socio-economic status etc.). Added some cited articles through the reference list of a few papers.

Added to Endnote file when relevant.

Total of 65 papers.

After a screening of titles and abstracts, 48 papers were discarded as not or less relevant to our research question. The remaining 17 publications form the basis of the current review. 




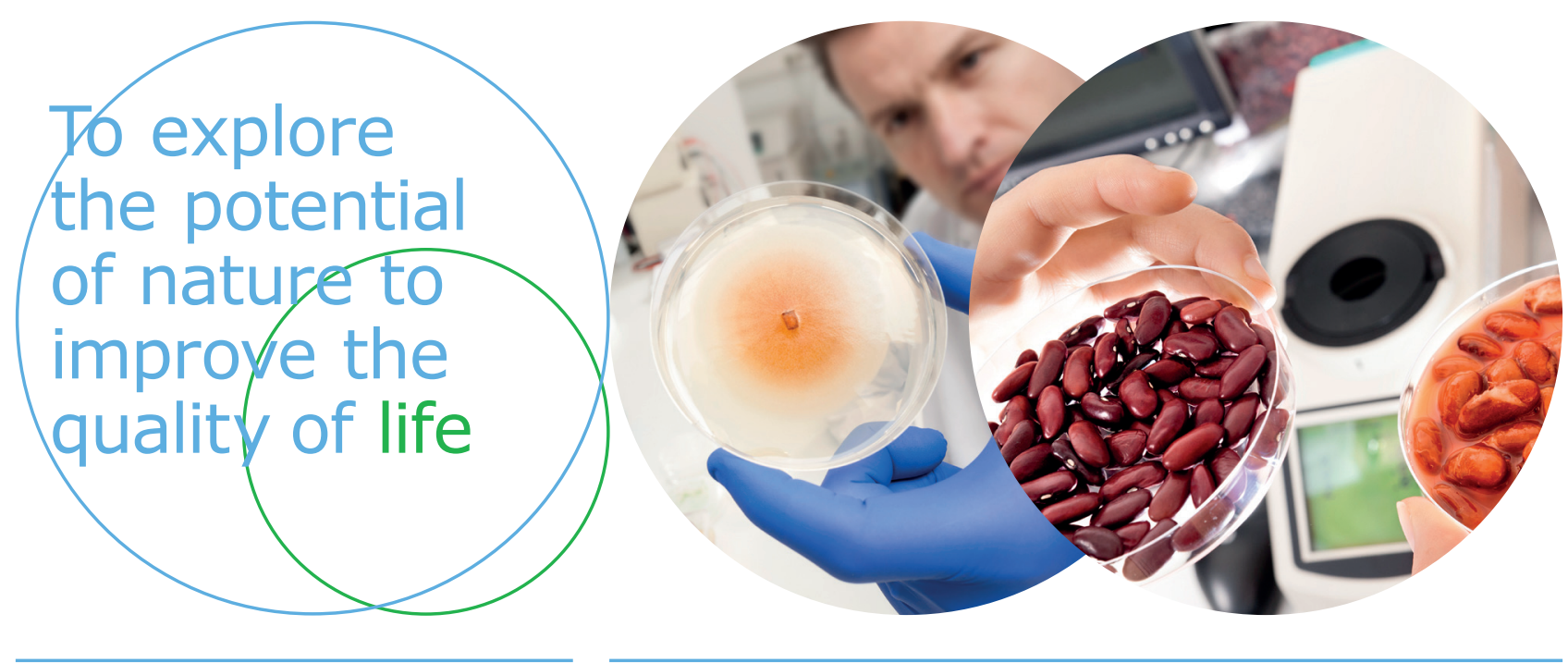

Wageningen Food \& Biobased Research Bornse Weilanden 9

6708 WG Wageningen

www.wur.nl/wfbr

info.wfbr@wur.nl

Rapport 2041

ISBN 978-94-6395-383-2
De missie van Wageningen University \& Research is 'To explore the potential of nature to improve the quality of life'. Binnen Wageningen University \& Research bundelen Wageningen University en gespecialiseerde onderzoeksinstituten van Stichting Wageningen Research hun krachten om bij te dragen aan de oplossing van belangrijke vragen in het domein van gezonde voeding en leefomgeving. Met ongeveer 30 vestigingen, 5.000 medewerkers en 12.000 studenten behoort Wageningen University \& Research wereldwijd tot de aansprekende kennisinstellingen binnen haar domein. De integrale benadering van de vraagstukken en de samenwerking tussen verschillende disciplines vormen het hart van de unieke Wageningen aanpak. 